CGIR

\title{
The structure of corporate groups: the Italian Case
}

\author{
Published on \\ “Corporate Governance - An International Review”, January, 1999.
}

\author{
Alessandro Zattoni \\ Istituto di Economia aziendale \\ Università Commerciale L. Bocconi \\ Viale Isonzo 23, 20135 - Milano \\ Tel: 02 - 5836.2527 or .6851 \\ Fax: 02 - 5836.2530 \\ email: alessandro.zattoni@uni-bocconi.it
}




\section{Alessandro Zattoni}

\section{THE STRUCTURE OF CORPORATE GROUPS: THE ITALIAN CASE}

Large firms all over the world conduct their business through a number (tens or hundreds) of subsidiaries and associated companies, the single company that conducts its business without equity ties with other firms is nowadays the legal form adopted only by small enterprises. The corporate group is typical not only of developing countries such as Nicaragua or India, or of countries of late industrialisation such as Germany and Japan, but it is also the usual legal structure adopted in Anglo-Saxon countries such as the United States and the United Kingdom (Strachan, 1976; Chandler, 1982; Goto, 1982; Encaoua, Jacquemin, 1982; Tricker, 1984; Wymeersch, 1994; etc.)

There are many reasons why firms adopt this complex structure: to minimise tax burdens, to follow the internationalisation process, to isolate the risks involved in certain activities or businesses, to take advantage of some legal regulations, and so on (Bonbright, Means, 1932; Hadden, 1984; Tricker, 1994; Zattoni, 1997; etc.). Depending on the objectives pursued, managers can create separate legal entities to govern single functions of the firm (production, sales, R\&D, etc.), single businesses (insurance, manufacturing, services, etc.) or parts of businesses (products, brands, geographical areas, etc.).

Previous studies show that corporate groups tend to be characterised by company structures that differ according to the country of incorporation of the parent companies. This means that groups with parent companies located in the same country tend to have homogeneous characteristics (organisational isomorphism) ${ }^{1}$ and that groups located in different countries have different features. In other words, the legal, social and cultural institutions of the host country seem to have a great influence on company structure. 
That being said, the main aim of this article is to describe the characteristics of large firms in Italy and to analyse the reasons that lead to the adoption of a complex company structure. With this aim in mind, the first part of this article will describe the characteristics of large Italian firms in terms of structure of control and ratio of shares owned by the main shareholder, comparing them with other countries; the second part of the article will analyse the typical company structure adopted by large Italian firms, explaining the reasons that justify such widespread use of pyramidal (or hierarchical) holding companies in this country. Finally, the consequences that this structure has had on the performance of groups and on the Italian economic system will be discussed, with some insights on future trends.

\section{THE STRUCTURE OF CONTROL OF ITALIAN FIRMS}

In the last decade, the characteristics of the different forms of "Capitalism”, also called "Systems of Corporate governance", typical of the main industrialised countries have been described in many articles and books. These studies show that there are two models facing each other: the Anglo-Saxon model and the German-Japanese model (Chandler, 1990; Albert, 1991; Charkham, 1994; etc.). In the former, ownership is divided among a large number of shareholders, managers have control of the firms and the market for corporate control reallocates the control of firms badly managed through hostile take-overs; in the latter, banks and in general financial institutions finance a large part of the firms' investments (through both debt and equity) and for this reason they play a large role, directly or through the election of managers, in the management of the firms. 
The Italian case differs from both: in fact in Italy there is no market for corporate control developed in the way it is in Anglo-Saxon countries and, due to the previous Banking Law, banks do not own large shareholdings in industrial companies ${ }^{2}$. A description of the shareholding structure and the company structure of large firms in Italy now follows with the purpose of pointing out the main peculiarities of the Italian system of Corporate governance.

(insert here Table 1)

a) The shareholding structure of large Italian firms

As can be seen in Table 1, whose data regard only stock companies which are based in four different countries, foreign shareholders represent the smallest percentage among the countries considered, public administration (Government and local authorities) the highest, institutional investors the second lowest, financial institutions the lowest, firms the second lowest (however data concerning the United Kingdom tend to underestimate inter-group shareholdings because of the accounting standards used) and finally families represent by far the highest percentage. So from these data, which obviously describe the situation only at an aggregate level, we know that Italian firms have a peculiar distribution of shareholdings: in fact they nearly always have the lowest or the highest percentage for each category of shareholders ${ }^{3}$.

Moreover, from data regarding the ratio of issued shares owned by the main shareholder, we learn that large Italian firms are also characterised by a larger concentration of the ownership structure. From a comparison at international level, it results that in the first 500 Italian (not financial) firms per revenue the main shareholder has in more than $96 \%$ of the cases the control ( $>51 \%$ of the shares) of the firm; the same 
percentage in the first 500 (not financial) companies in France is equal to 55\%, in the first 400 in Germany to $66 \%$ and in the first 470 in the United Kingdom to 5.3\%. Using data regarding the United States and Japan, it results that Italian firms have a larger concentration of shares in the hands of the main shareholder also compared to these countries (Barca et al., 1994).

In short, large Italian firms are characterised by a greater concentration of shares in the hands of the main shareholder and, moreover, this shareholder is, in the majority of the cases, a coalition of people belonging to the same family. This datum, which can be considered anomalous and strange if judged by international standards, confirms one of the main peculiarities of Italian capitalism, i.e. the strong influence of the owner family in large-sized firms ${ }^{4}$.

These data show that the Italian system of Corporate governance is characterised both by a peculiar distribution of shareholdings and by a larger concentration of shares in the hands of the main shareholder, but they do not allow us to infer anything about the weight of the different ownership structure among large Italian firms. The main limit of the data presented is that they do not show the distribution of shareholders for homogeneous categories of firms (multinational, family-owned, State-owned, cooperatives, and so on) ${ }^{5}$; i.e. from these data it seems that all firms in Italy are controlled by one family or coalitions of individuals, which is obviously not the case.

b) The structure of control of large corporate groups in Italy

A recent study has supplied data which were previously missing and enables us to measure the weight of different structures of control among large Italian firms and groups (Ravasi, Zattoni, 1997). The study considered all the firms incorporated in Italy 
in all industries (excluding banking, insurance and financial services) with more than 100 employees and 300 billion revenue lire in 1995.

By collecting information through many different sources (published data, economic magazines, questionnaires, etc.), the authors were able to reconstruct the ownership structure and the corporate structure of almost all the firms analysed. The rule they used to assign the "structure of control" to each firm was the ownership of the majority of the company's shares (i.e. >51\%). Moreover, because previous studies showed the widespread use of holding companies controlling a large number of firms, they decided to pass through the corporate veil and consider all the firms controlled by the same parent company as one single entity; i.e. they measured the size of corporate groups instead of single firms belonging to them.

The main results of the study, presented in Table 2, show that:

- large firms incorporated in Italy represent a composite and varied set of structure of control, even if three types count for about $90 \%$ of the total revenue and employees;

- there is a strong prevalence of ownership structures characterised by one shareholder (one person, the State or one multinational firm) or more shareholders connected by family ties controlling the majority of the shares;

- it is not common to find firms controlled by coalitions, in which two or more shareholders (not connected by family ties) share the control of the firms;

- at the moment in Italy there are no financial and industrial groups as in Japan and Germany and we can count only one public company among the largest firms and groups of the country.

In short, these data show that the large firms incorporated in Italy are mainly controlled by the main shareholder (the State or a multinational firm) or by more shareholders 
belonging to the same family. In particular, it is surprising to note that such a large amount of groups and firms, equal to $1 / 3$ of total revenue and more than $1 / 3$ of total employees, are still controlled by single families, in many cases represented by the founder or heirs.

(insert here Table 2 and its Legend)

A partial explanation to this situation is that Italian firms tend to do business in traditional and specialised industries, i.e. they tend to create firms in industries in which the controlling shareholder must not realise high investments right from the start (Porter, 1990; Dematté, Corbetta, 1993). Moreover, after the birth of the firm, Italian entrepreneurs prefer to create group of companies (with or without equity ties) that work together in order to produce the final product, instead of increasing the size of their firms too much and too soon (Lorenzoni, 1990).

Nevertheless, if this reasoning explains why the Italian economy is dominated by small and medium-sized enterprises controlled by one family, it does not clarify why many large companies in the country are also still controlled by one family or by a coalition of families. Moreover, data not presented here show that single families tend to maintain the control not only of firms and groups operating in traditional or specialised industries (as for example textiles, furnishing, shoes, mechanical, etc.), but also of firms operating in scale intensive or scale-based industries (as for example the production of automobiles and trucks, white goods, steel, food, etc.) where it is important to grow through a stable and high rate of investment (in R\&D, physical assets, marketing, etc.) over a long time period ${ }^{6}$. In order to find a solution to this puzzle, the next paragraph will describe the typical company structure of large Italian firms. 


\section{THE COMPANY STRUCTURE OF LARGE ITALIAN GROUPS}

Some characteristics of Italian corporate groups help to explain why so many large-sized firms are still controlled by one single family. Large Italian groups are characterised by a pyramidal structure at the head of which there is a holding company, that is the managing centre of all the group's activities. Between the holding company and the operating firms, there is usually a number of sub-holdings with different characteristics and purposes.

In particular, the number of levels and the ratio of shares owned by the parent company in the sub-holdings seem to depend, among other things, on the amount of funds necessary to pursue the development and the competitive advantage of firms belonging to the group on the one hand, and, on the other, on funds made available by the controlling family. In order to solve the conflicting requirements of businesses and family, large private Italian groups use different techniques such as: a) creating many levels of subsidiaries between the holding and the operating companies (stock pyramiding effect); b) listing the securities of many companies belonging to the group; c) issuing shares without (or with limited) voting rights; d) making large use of debt for financing the assets; e) setting up mutual shareholdings with other groups. All these variables are strictly connected to one another, i.e. they constitute a system whose aim is to allow the main shareholder of the holding company to maintain the control of a large amount of assets. There now follows a brief description of all these characteristics.

a) The stock pyramiding effect

The stock pyramiding is an old technique (in fact it was used at the end of the last century by American railway companies) that allows controlling shareholders to control 
the largest possible number of firms (i.e. amount of assets) with the lowest amount of money (Clemens, 1950; Hilferding, 1968). In order to understand how this mechanism works, we hypothesise that: 1) one shareholder wants to maintain certain control of some assets, incorporated in company A, minimising his personal investment; 2) these assets have a total value of, say, $\$ 1,000 ; 3$ ) all the firms are equally financed by equity and debt (50\% debt and $50 \%$ equity). In these circumstances, if the firm that incorporates these assets (company A) is directly controlled by the main shareholder, this person should invest 51\% of the equity of this firm, i.e. $\$ 260$ (about 51\% of 500), in order to maintain control of the company. Suppose now this shareholder creates a new company (company B), with assets for \$260 financed through debt (\$130) and equity (\$130), to which he sells his shareholding in company A. If company B is a financial firm without any other assets than the majority shareholding in company A (having a value of \$260), the main shareholder can now control the assets investing only a quarter of the money ( $\$ 70$, about $51 \%$ of 130 ), i.e. the amount necessary to control $51 \%$ of the equity of company $B$. In general, the higher the number of subsidiaries created, the lower the investment the controlling shareholder needs to make to maintain control of the assets: with three levels, $\$ 18$ will suffice; with four, $\$ 5$ only, and so on (see Table $3)$.

This mechanism is also more powerful, i.e. a smaller amount of money is enough to control the assets, if: 1) the shareholders of the holding company control the firms at any level with less than $51 \%$ of the shares; 2 ) the companies issue shares without (or with limited) voting rights; 3) there are mutual shareholdings between firms at different levels ${ }^{7}$; 4) the firms have a high leverage. In short, diluting the investments in shares of non-controlling shareholders in many companies and concentrating the ones of 
controlling families at the top allows the largest shareholders of the holding company to control a large number of firms (i.e. a large amount of assets) with a small investment in shares in the top company ${ }^{8}$.

Obviously, this mechanism works only if the controlling shareholder succeeds in convincing a large number of savers to buy shares in firms belonging to the group. This means that top company managers should be able to obtain a profit high enough to reward (through dividends and capital gains) the minority shareholders involved in the firms of the group. Regarding this point, research with data on Italian groups with listed companies has shown that the separation between controlling and minority shareholders is low: in fact, on average, for each unit of equity of the holding company the controlling shareholders are able to collect only one and a half units from shareholders involved in the financing of other firms belonging to the same group. However, a further analysis has shown that this average is misleading because if State-owned groups and banks hardly ever use this mechanism, family-controlled groups are able to multiply the unit of capital invested in the holding company by eight ${ }^{9}$. A good example of pyramidal structure is Pirelli group, whose structure is presented in Figure $1^{10}$.

(insert here Table 3 and Figure 1)

b) Listing the securities of many companies belonging to the same group

During the past decades, and particularly during the peaks of the stock-exchange, large corporate groups listed many companies under their control. These listings had two financial benefits for the controlling family: an immediate flow of capital due to the sale of a large amount of shares and the possibility to collect funds in the future both through the selling of shares not necessary for the control and through capital increasing. 
Moreover the listing of so many companies of the same group gave controlling shareholders the possibility to solve financial crises in some of the group's firms or businesses through capital increase in subsidiaries with good economic performance.

In Table 4, data regarding the gross capitalisation of main corporate groups in absolute terms and the percentage on the total capitalisation of the Italian stock-exchange are given. The data show that during the last fifteen years, even with some differences due to the listing of new companies and the exit of others, the importance of the main groups on the value of the market has been very high and stable; in particular the first corporate group per capitalisation counts for more than $1 / 5$ of the market, the first three groups for half of the market and the first ten groups for about $80 \%$ of the total capitalisation. The first ten groups per capitalisation controlled 47 firms with listed shares, with a minimum of zero to a maximum of 16 , at the end of 1996.

(insert here Table 4)

c) Issuing shares without or with limited voting rights

Another legal device used by owner families to collect funds without losing the control of their group is represented by the issuing of shares without voting rights (saving shares) or with limited voting rights (preferred shares). This device can be used profitably almost exclusively by listed companies, because if the controlling group wants external shareholders to buy these stocks, the shares should be easily tradable. Moreover, the law allows only listed companies to issue saving shares and in any case shares with limited voting rights cannot be issued for an amount higher than the value of the shares with full voting rights (ordinary shares). 
In the '80s many groups took advantage of this opportunity, increasing the capital of listed companies through the issue of non-voting shares. As can be seen in Table 5 , the nominal value of preferred and saving shares increased in the ' 80 s reaching $21.6 \%$ of the nominal value of all listed shares by the end of 1988; since then things have changed and in June 1997 the same percentage had decreased to $11.0 \%$. The reason for this fall is that this technique does not seems to satisfy completely the interests of either the controlling family (because of the higher rate of dividends due to these shares in exchange for the limitations on voting rights) or the external shareholders (because the value of these stocks is generally much lower than that of shares with full voting rights). (insert here Table 5)

\section{d) High leverage}

Italian companies are characterised by a higher ratio of debt to capital compared to firms located in other countries. This empirical evidence is explained by many reasons: 1) firms with large debts have fiscal advantages because interest is deductible from tax and dividends are not ${ }^{11} ; 2$ ) in some cases the controlling shareholders prefer to finance the firms through new debt, buying long-term bonds issued by the firms themselves, because this option allows them to get taxes relief on personal income; 3) increasing the debt (within limits) enables controlling shareholders both to finance all the required investments and to maintain control of the firm. During the last few decades this ratio has improved: it was particularly high during the '70s, when equity was on average equal to $17 \%$ of the total investments of the firms, but then in the ' 80 s it rose to $27 \%$ and in the '90s it has reached 30\% (Mediobanca, 1996). 
A large part of the debt consists of loans from banking and financial institutions, which therefore play an important role in financing Italian firms. However a financial structure with high leverage is very fragile, especially when it involves holding companies (which receive money through flows of dividends); for this reason in the last decades more than one group has collapsed or has been forced to sell different assets in order to maintain control of its remaining businesses. Almost all the large groups that today are controlled by a coalition of banks and financial institutions are groups previously controlled by one family that collapsed for financial reasons.

e) Mutual inter-group shareholdings

Large Italian groups tend to create a web of mutual shareholdings among themselves that constitutes one of their main peculiarities. These equity ties are both one-way and two-way, sometimes they represent portfolio investments, more often they help guarantee control of the group. They are minority shareholdings that represent a consistent investment and that, if aggregated, can also be equal or greater than the controlling shareholdings of the owner family.

In order to give an idea of the entity of the phenomenon it is sufficient to remember that the capitalisation of inter-group equity links at the end of 1987 was equal to 7,404 billion lire (equal to $6.4 \%$ of the gross capitalisation of the stock-exchange). About one third of these inter-group shareholdings were held by Mediobanca, a merchant bank that, in the continuous search for funds by the controlling family, has been playing the conclusive role of hidden director able to favour the control held by the existing majority (Brioschi, Buzzacchi, Colombo, 1990). These investments in shares are characterised by continuous adjustments that seem to be governed by the will to help 
create a stable group of controlling shareholders. Some relevant facts bring us to this interpretation: 1) 95\% of the inter-group equity links at the end of 1987 were constituted by investments in common shares (with full voting rights); 2) during the '80s, shareholdings in subsidiaries in which the owner family had obtained a majority control were turned into shareholdings in holding companies in which the controlling family owned less than $51 \%$ of the shares with voting rights; 3 ) the financial alliance between the controlling family and friend groups tends to be formalised in voting trust, which binds shareholders to vote in the same way at the shareholders' meetings, or blocking trust, which prevents shareholders from selling the shares to other investors ${ }^{12}$.

\section{CONCLUSIONS}

Large Italian companies tend to be structured as pyramidal groups made up of many levels of firms, not always controlled with at least $51 \%$ of the shares. One of the main peculiarities of Italian groups is that the first levels from the top are usually represented by listed companies in which the main shareholder (the owner family) maintains the control only thanks to the decisive help of shares held by other friend companies. In general, we can conclude that the characteristics of the first levels of Italian groups are aimed at assuring the control of the largest amount of assets with the smallest amount of funds. Then, under these levels, the structure of Italian corporate groups tends to be more similar to the structure of groups localised in other countries, i.e. under the third or fourth level from the top we find not-listed companies with responsibility in some industry or business and controlled with a very high percentage of equity. That being stated, in the remaining part of the article some comments will be made on the 
consequences that these pyramidal structures, and the stability of control they allow, can have on the performance of large Italian firms.

According to scholars, the stability of ownership represents a positive aspect of a Corporate governance system because large and stable shareholders can prevent firms from being managed towards myopic objectives such as, for instance, short-term profitability. Many authors have in fact criticised the investment policy adopted in the past decades by Anglo-Saxon public companies because it was too sensitive to current returns and it stressed current stock price over long-term corporate value (Porter, 1992). Moreover, scholars have also underlined that strong shareholders are able to control the boardroom, so that managers cannot pursue personal aims, deviating from the objective of maximising the shareholders' value.

On the other hand, the majority control of firms belonging to the group prevents potential raiders from attempting hostile take-over, even when there is the feeling that the firm can be better managed by someone else. Pyramidal structure like the one adopted by Italian groups creates potential risks for minority shareholders because controlling shareholders of the holding company can be tempted to increase the wealth of firms in which they have the greatest ratio of equity (i.e. of dividends) through the mechanism of transfer price applied on inter-group trade (regarding goods, services or loans).

Moreover, in the past decades, due to the financial fragility of pyramidal structure events such as sudden and unexpected economic crises in some businesses frequently emerged, forcing firms to find a large amount of funds in a short amount of time to solve the financial problems which had arisen. The solution to these problems was usually for the owner family to list some of the group's firms on the stock- exchange 
(usually the ones with good economic and financial performances) and to modify the structure of the group (mergers, break-ups, capital increases, and so on). In other cases, they left the control of some of the group's companies, if not of all of them, in other hands.

Finally, the fragility of the financial structure of large Italian groups, due to the wish of controlling shareholders to maintain control of a large amount of assets, has probably in some circumstances damaged the competitive position of some controlled businesses. In some cases the owner family may have preferred to maintain control of the group taking further financial risks, instead of realising the investments (in R\&D, marketing, physical assets, and so on) required by the competitive challenge. The financial fragility of this structure could have also helped prevent the development of many capital intensive and high technology firms owned by private shareholders. Compared to these pyramidal structures, both public companies, typical of Anglo Saxon capitalism, and industrial and financial groups, typical of the German and Japanese model, have superior characteristics in terms of ability to finance growth through periodical and frequent increases in capital. In the past decades, the State, in some circumstances, filled this gap creating giant firms operating in scale intensive or science based industries (such as steel, public utilities, defence, and so on), but this option will not be possible in the future because of the strict financial budget the Government is imposing on State-owned groups.

Before concluding, here are some comments on future trends. In the next years the pyramidal structures that characterise large corporate groups are likely to become simpler and the ownership structure of holding companies at the top may become more 
fragmented among coalitions of different shareholders. This trend is suggested by many signs:

a) the increasing awareness of businessmen that in a global financial market, pyramidal structures including many companies with listed shares can divert large amount of funds from the Italian stock-exchange because they produce a less transparent and efficient market, they prevent hostile take-overs and cause a structural conflict of interests between majority and minority shareholders ${ }^{13}$;

b) the privatisation process is placing giant firms and groups on the stock-exchange market; these groups will be controlled by coalitions of different parties such as banks, firms, employees, institutional investors, and so on, either for the sales conditions fixed by the Government or for the large amount of funds required to control the board;

c) the new Banking Law has allowed banks and other financial institutions to take control of industrial firms; until now they used this possibility mainly for saving industrial groups in financial crisis, but when the current merger and acquisition phase in the financial industry is complete, they could become important shareholders in many industrial companies;

d) due to the sharp decrease in interest rates on bonds, in the next decades mutual and pension funds will attract a larger proportion of savings that will be invested mainly in listed companies;

e) the globalisation process and the birth of the European Monetary Union will force many firms to grow in order not to lose competitive advantage; this means that controlling shareholders who do not have enough funds to finance the investments required to be competitive on the market should involve external investors and consequently jeopardise their control. 
Today it is difficult to foresee if the ownership structure of large Italian firms and groups will become more similar to Anglo-Saxon public companies or to German industrial and financial groups. Probably, considering the long time period required to change cultural, political, and economic institutions (North, 1994), Italian corporate groups will continue to differ from both in some particular features.

\section{References}

Airoldi, G., "Capitalism Models and Enterprise Models: Methods of Comparative Analysis", in: Airoldi, G., Amatori, F., Invernizzi, G., (edited by), Ownership and Governance: the Case of Italian Enterprises and Public Administration, Milano: EGEA, 1995.

Albert, M., Capitalisme contre Capitalisme, Paris: Seuil, 1991.

Barca, F., et al., Assetti proprietari e mercato delle imprese, vol. I and II, Bologna: Il Mulino, 1994.

Berle, A., Means, G.C., The Modern Corporation and Private Property, New York: MacMillan, 1932.

Bonbright, J.C., Means, G.C., The Holding Company, New York: McGraw-Hill, 1932.

Brioschi, F., Buzzacchi, L., Colombo, M.G., Gruppi di imprese e mercato finanziario, Roma: La Nuova Italia Scientifica, 1990.

Cannari, L., Marchese, G., Pagnini, M., "Forma giuridica, quotazione e struttura proprietaria delle imprese italiane: prime evidenze comparate", in: Banca d'Italia, Il mercato della proprietà e del controllo delle imprese: aspetti teorici e istituzionali, Roma: Banca d’Italia, 1994. 
Chandler, A.D., "The M Form: Industrial Groups, American Style", European Economic Review, n. 19, 1982.

Chandler, A.D., Scale and Scope - The Dynamics of Industrial Capitalism, Cambridge: Harvard University Press, 1990.

Charkham, J.P., Keeping Good Company: a Study of Corporate Governance in five Countries, Oxford: Clarendon Press, 1994.

Clemens, E.W., Economics and Public Utilities, New York: Appleton Century Crofts, 1950.

Consob, Relazione per l'anno 1996, 1997.

Dematté, C., Corbetta, G., I processi di transizione delle imprese familiari, Milano: Mediocredito Lombardo, 1993.

Encaoua, D., Jacquemin, A., "Organizational Efficiency and Monopoly Power - The Case of French Industrial Groups", European Economic Review, n.19, 1982.

Goto, A., "Business Groups in a Market Economy", European Economic Review, n.19, 1982.

Hadden, T., "Inside Corporate Groups", International Journal of the Sociology of Law, 12, 1984.

Hilferding, R., Das Finanzkapital, Frankfurt am Main: Europaische Verlagsstalt, 1968.

Lorenzoni, G., L'architettura di sviluppo delle imprese minori: costellazioni e piccoli gruppi, Bologna: Il Mulino, 1990.

Mediobanca, Dati cumulativi di 1746 società italiane, 1996.

Mediobanca, Indici e dati, 1997.

North, D. C., Institutions, Institutional Change, and Economic Performance, Cambridge: Cambridge University Press, 1994. 
Orrù, M., Biggart, N.W., Hamilton, G.G., "Organizational Isomorphism in East Asia", in: Powell, W.W., Di Maggio, P.J., (edited by), The New Institutionalism in Organizational Analysis, Chicago: University of Chicago Press, 1991.

Pavitt, K., "Sectoral Patterns of Technical Change: Towards a Taxonomy and a Theory", Research Policy, vol. 13, 1984.

Porter, M., The Competitive Advantage of Nations, London: MacMillan, 1990.

Porter, M.E., "Capital Disadvantage: America’s Failing Capital Investment System", Harvard Business Review, September-October, 1992.

Ravasi, D., Zattoni, A., “Assetti proprietari e distribuzione settoriale delle grandi imprese italiane”, working paper, 1997.

Ricerche e Studi, R\&S, 1997.

Strachan, H., Family and other Business Groups in Economic Development, New York: Praeger Publishers, 1976.

Tricker, R.I., Corporate Governance, Aldershot: Gower Publishing, 1984.

Tricker, R.I., International Corporate Governance - Text, Readings and Cases, London: Prentice Hall, 1994.

Wymeersch, E., "Aspects of Corporate Governance in Belgium", Corporate Governance - An International Review, n.3, 1994.

Zattoni, A., “Le aziende italiane”, in: Cortesi A. (edited by), Economia aziendale - Casi, Milano: EGEA, 1994.

Zattoni, A., “I gruppi di imprese”, Sviluppo \& Organizzazione, novembre-dicembre, 1997. 
Table 1: Owners of shares in public companies in France, Germany, Italy and the United Kingdom in 1991 (data in percentage on the total).

\begin{tabular}{|l|r|r|r|r|}
\hline Shareholders & \multicolumn{1}{l|l|l|}{ ll } & \multicolumn{1}{l|}{ lancermany } & \multicolumn{1}{l|}{$\begin{array}{l}\text { Italy } \\
\text { Kingdom }\end{array}$} \\
\hline Families & 27.0 & 16.9 & 50.8 & 13.3 \\
\hline Firms & 49.1 & 39.5 & 24.0 & 7.5 \\
\hline Financial Institutions & 6.6 & 11.8 & 6.3 & 19.4 \\
\hline Institutional investors & 3.4 & 13.2 & 3.9 & 36.3 \\
\hline Public administration & 4.2 & 5.5 & 8.2 & 1.9 \\
\hline Foreign investors & 9.7 & 13.1 & 6.8 & 21.6 \\
\hline Total & 100.0 & 100.0 & 100.0 & 100.0 \\
\hline
\end{tabular}

Source: Cannari et al., 1994..

Table 2: Ownership structure of large firms incorporated in Italy at the end of 1995

\begin{tabular}{|l|r|r|r|r|r|}
\hline & $\begin{array}{l}\text { Number } \\
\text { of } \\
\text { groups }\end{array}$ & $\begin{array}{l}\text { Total } \\
\text { revenue } \\
\text { in } £ \text { it. }\end{array}$ & $\begin{array}{l}\text { Revenue in \% } \\
\text { on the total }\end{array}$ & $\begin{array}{l}\text { Total } \\
\text { employees }\end{array}$ & $\begin{array}{l}\text { Employees in } \\
\text { on } \\
\text { total }\end{array}$ \\
\hline $\begin{array}{l}\text { Coalition of banking and } \\
\text { financial institutions }\end{array}$ & 3 & $11,733,159$ & $1.66 \%$ & 38,068 & $2,24 \%$ \\
\hline Coalition of families & 20 & $29,956,682$ & $4.24 \%$ & 79,174 & $4.66 \%$ \\
\hline Coalition of different subjects & 7 & $4,348,085$ & $0.62 \%$ & 9,568 & $0.56 \%$ \\
\hline Co-operatives & 16 & $14,524,484$ & $2.06 \%$ & 35,988 & $2.12 \%$ \\
\hline Family & 142 & $240,375,249$ & $34.05 \%$ & 665,270 & $39.16 \%$ \\
\hline Joint venture & 9 & $15,462,851$ & $2.19 \%$ & 36,483 & $2.15 \%$ \\
\hline Foreign multinational firm & 133 & $173,777,998$ & $24.61 \%$ & 288,003 & $16.95 \%$ \\
\hline State or local authorities & 8 & $207,351,405$ & $29.37 \%$ & 531,109 & $31.27 \%$ \\
\hline Other forms & 2 & 805,704 & $0.11 \%$ & 1,601 & $0.09 \%$ \\
\hline Not classifiable & 12 & $7,714,168$ & $1.09 \%$ & 13,459 & $0.79 \%$ \\
\hline Total & $\mathbf{3 5 2}$ & $\mathbf{7 0 6 , 0 4 9 , 7 8 5}$ & $\mathbf{1 0 0 . 0 0 \%}$ & $\mathbf{1 , 6 9 8 , 7 2 3}$ & $\mathbf{1 0 0 . 0 0 \%}$ \\
\hline
\end{tabular}

Source: elaboration on data of Ravasi, Zattoni, 1997.

\section{Legend:}

Structure of control

Coalition of banking and financial institutions

Coalition of families

Coalition of different subjects

Co-operatives

Family

Joint venture

Foreign multinational firm

State or local authorities

Other forms

Not classifiable
Subjects controlling the firm

A large number of banking and financial institutions Two or more persons belonging to different families Coalition among families, banking and financial institutions, managers, industrial firms, etc.

Large number of shareholders that are consumers, employees, etc.

One or more persons belonging to the same family

Two firms with the same amount of shares (50\%)

One multinational firm with the headquarters located in a foreign country.

State or some local authority

It is a residual group including one public company and one firm controlled by a foundation

Firms for which it has not been possible to identify the shareholders 
Table 3: The stock pyramiding effect

\begin{tabular}{|l|r|l|l|l|l|}
\hline Company & Assets & Equity & $\begin{array}{l}\text { Controlling } \\
\text { shareholder' } \\
\text { equity }\end{array}$ & $\begin{array}{l}\text { Minority } \\
\text { shareholder' } \\
\text { equity }\end{array}$ & Debt \\
\hline A & 1,000 & 500 & 260 & 240 & 500 \\
\hline B & 260 & 130 & 70 & 60 & 130 \\
\hline C & 70 & 35 & 18 & 17 & 35 \\
\hline D & 18 & 9 & 5 & 4 & 9 \\
\hline
\end{tabular}

Table 4: Gross capitalisation of Italian large corporate groups (in value and in percentage on the total capitalisation of the stock-exchange)

\begin{tabular}{|c|c|c|c|c|c|c|}
\hline & \multicolumn{2}{|l|}{ End 1980} & \multicolumn{2}{|l|}{ End 1987} & \multicolumn{2}{|l|}{ End 1996} \\
\hline $\begin{array}{l}\text { Gross capitalisation } \\
\text { regarding: }\end{array}$ & $\begin{array}{l}\text { Value in } \\
\text { billion } £ \text { it. }\end{array}$ & $\%$ on total & $\begin{array}{l}\text { Value in } \\
\text { billion } £ \text { it. }\end{array}$ & $\%$ on total & $\begin{array}{l}\text { Value in } \\
\text { billion } £ \text { it. }\end{array}$ & $\%$ on total \\
\hline - first group & 6,445 & 26.07 & 29,910 & 20.39 & 96,674 & 25.03 \\
\hline - first three groups & 11,486 & 46.47 & 77,139 & 52.59 & 200,451 & 51.9 \\
\hline - first five groups & 14,808 & 59.91 & 105,102 & 71.65 & 248,213 & 64.27 \\
\hline - first ten groups & 19,237 & 77.83 & 122,096 & 83.24 & 296,828 & 76.86 \\
\hline
\end{tabular}

Source: data regarding 1980 and 1987 are taken from Brioschi, Buzzacchi, Colombo, 1990; data regarding 1996 are our elaboration on Italian stock-exchange data.

Table 5: Nominal value (in billion $£$ it.) of common shares versus preferred and saving shares of companies listed on the Italian stock-exchange

\begin{tabular}{|c|c|c|c|c|c|c|c|c|}
\hline & \multicolumn{2}{|l|}{ End 1979} & \multicolumn{2}{|l|}{ End 1983} & \multicolumn{2}{|l|}{ End 1988} & \multicolumn{2}{|l|}{ July 1997} \\
\hline & $\begin{array}{l}\text { Value in } \\
\text { billion } £ \text { it. }\end{array}$ & $\%$ on total & $\begin{array}{l}\text { Value in } \\
\text { billion } £ \text { it. }\end{array}$ & $\%$ on total & $\begin{array}{l}\text { Value in } \\
\text { billion } £ \text { it. }\end{array}$ & $\%$ on total & $\begin{array}{l}\text { Value in } \\
\text { billion } £ \text { it. }\end{array}$ & $\%$ on total \\
\hline $\begin{array}{l}\text { Common } \\
\text { shares }\end{array}$ & 7,496 & 95.8 & 15,109 & 89.3 & 30,131 & 78.4 & 97,440 & 89.0 \\
\hline $\begin{array}{l}\text { Preferred and } \\
\text { saving shares }\end{array}$ & 329 & 4.2 & 1,810 & 10.7 & 8,305 & 21.6 & 12,060 & 11.0 \\
\hline Total & 7,825 & 100.0 & 16,919 & 100.0 & 38,436 & 100.0 & 109,500 & 100.0 \\
\hline
\end{tabular}

Source: data regarding 1979, 1983 and 1988 are taken from Brioschi, Buzzacchi, Colombo, 1990; data regarding 1997 are our elaboration on data of Indici e dati (Mediobanca, 1997). 
Figure 1: The simplified company structure of Pirelli group in 1997

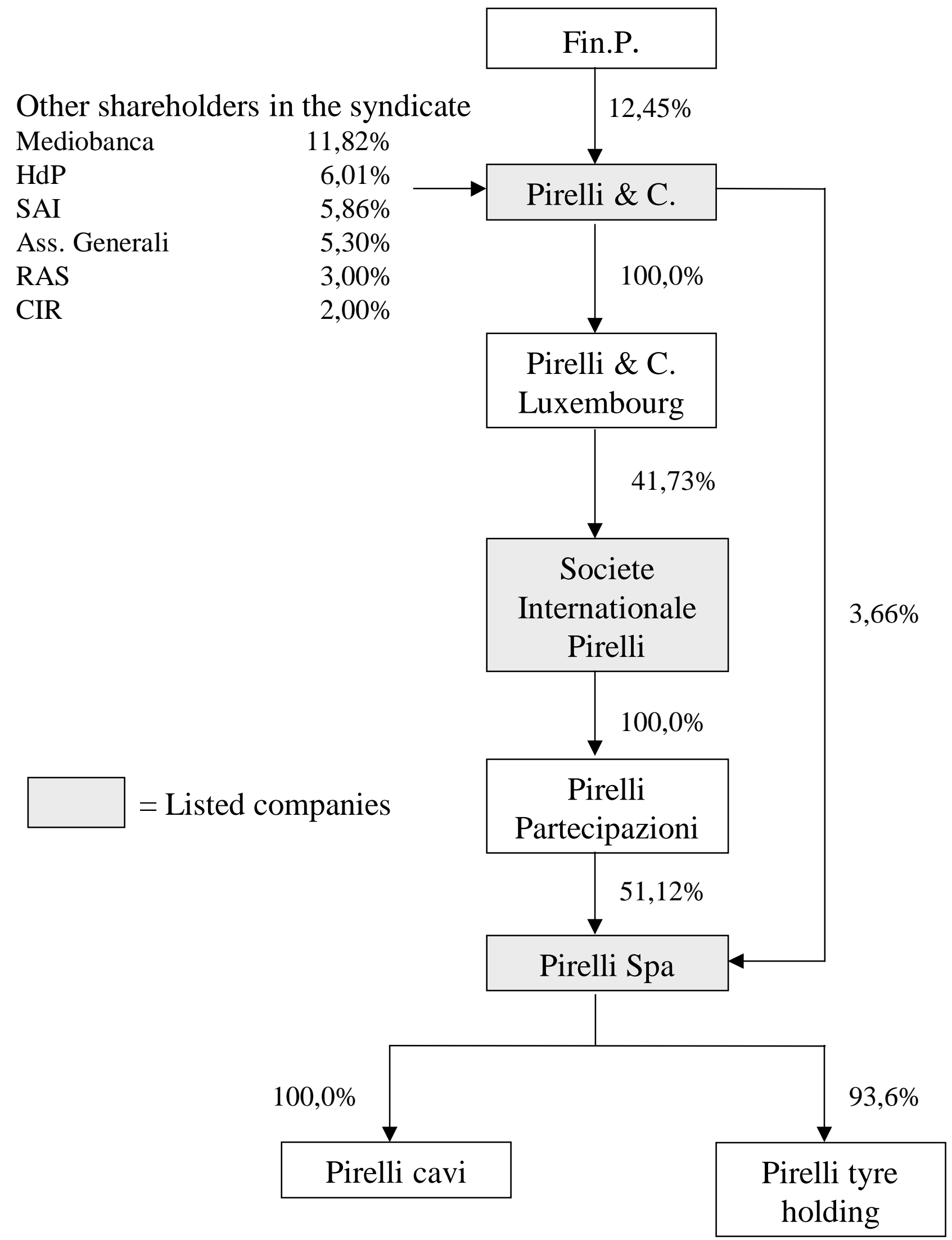


${ }^{1}$ On the concept of organizational isomorphism applied to corporate groups in East Asia see: Orrù, Biggart, Hamilton, 1991.

2 The new Banking Law ("Testo Unico delle Leggi in materia bancaria e creditizia”, August 27 ${ }^{\text {th }}$,1993) is based on the principle of de-specialisation, in the sense that grants to all financial institutions equal opportunities to develop activities at brief or medium-long term. In particular, banking institutions can, within certain limits, grant funds at medium-long term, issue bonds and buy industrial shares.

${ }^{3}$ Even if the privatization process diluted the ratio of shares in the hands of public administration and the new Banking Law (that allows financial institutions to buy shares in manufacturing firms) has created the opportunity to increase the percentage of shares owned by banks, official statistics say that, at the moment, the situation in Italy has only changed marginally from that described in table 1.

${ }^{4}$ Chandler showed that also in the United Kingdom many families maintained for a long time, and sometimes still have, a controlling position on founded firms; for this reason, he called the British experience "Personal capitalism" (Chandler, 1990). In any case, their shareholdings in large-sized firms are rarely so relevant as in Italy, where families maintain control of the majority of the shares in giant holding companies. As suggested by one referee, this difference could also be due to the fact that Italy is still behind in the evolution of the industrial and economic system; in fact a ten time larger percentage of Anglo-Saxon companies were privately controlled in 1900 than today.

${ }^{5}$ In Italy we can identify six typical models of "institutional structure" of firms: independent small and medium enterprises (SME), groups of SME, groups of firms owned by the State, large private groups, subsidiaries of multinationals, co-operatives. Each model has its own characteristics in terms of players (shareholders, lenders, managers, and so on), contributions given to the firm (money, technical ability, managerial ability, and so on) and rewards received in exchange (money, status, prestige, and so on) (Zattoni, 1994). On the concept of "institutional structure of the firm" see: Airoldi, 1995.

${ }^{6}$ The classification of industries here accepted is the one developed by Pavitt (Pavitt, 1984).

7 Italian groups do not very often use mutual shareholdings between the parent company and its subsidiaries, because the law imposes limits and restrictions to this kind of ties between firms.

${ }^{8}$ This case of separation between ownership and control is completely different from the one described by Berle and Means many years ago (Berle, Means, 1932). In that case, speaking about American giant public companies, they showed that these firms were governed by managers (without shares in the company) who were able to pursue their interests deviating from the objective of maximizing shareholders' value. Large Italian corporate groups present, instead, a case in which owners maintain control of the firm with a small amount of shares; in these circumstances the problems of Corporate governance regard mainly the risk of shareholders of the parent company pursuing their interests damaging those of minority shareholders of the subsidiaries.

${ }^{9}$ Also among family-controlled groups there is an high variability of cases; in particular, the highest value has been measured for Carlo De Benedetti and the Agnelli family with respectively a multiplier equal to 24 and 16 (Barca et al., 1994).

${ }^{10}$ Recently the shareholders of the group have decided to merge some financial subsidiaries with the objective of creating more value and increasing the transparency for the market.

${ }^{11}$ In order to reverse this phenomenon, the Government has recently changed fiscal rules lowering tax burdens on equity and increasing those on debt. Due to this law, it is reasonable to suppose that in the next few years Italian firms will have a better financial structure.

12 At the end of 1996 there were 56 voting and/or blocking trusts in listed companies that counted for about $30 \%$ of the total value of the Italian stock-exchange. The average shareholding of the pact is higher than $50 \%$ (Consob, 1997).

${ }^{13}$ Recently, the Corporate governance debate has captured the interests of politicians and the Italian Government. After a long period of study, the Draghi Commission produced a document in 1998 that has become law and that sets out new rules for firms and financial institutions working on financial markets. 